\title{
UBIQUITY OF TOXIGENIC FUNGI AND MYCOTOXINS IN ANIMAL FEEDS IN REPUBLIC OF SERBIA
}

\author{
V. Krnjaja ${ }^{1}$, J. Lević ${ }^{2}$, S. Stanković \\ ${ }^{1}$ Institute for Animal Husbandry, 11080, Belgrade-Zemun, Republic of Serbia \\ ${ }^{2}$ Maize Research Institute „Zemun Polje”, 11185, Belgrade-Zemun, Republic of Serbia \\ Corresponding author: VesnaKrnjaja.IZS@gmail.com \\ Invited paper
}

\begin{abstract}
Climatic conditions and growing of grain on large areas in Republic of Serbia are suitable for development of numerous toxigenic species, such as Fusarium spp., Aspergillus spp. and Penicillium spp., and resulting from this is frequent incidence of animal feed contamination by their toxic products. In Republic of Serbia, the most frequent fungi determined in animal feed are those from Fusarium genus, as well as their mycotoxins. Of Fusarium species the most frequent one is $F$. graminearum, and of toxins zearalenon, in maize or wheat grains, which are the main raw material in production of animal feeds. Development of this fungi and bio-synthesis of zearalenon most often depend on period of rains in the third decade of May when wheat is in the blossoming phenostage or on ample precipitation and low temperatures at the end of summer or beginning of autumn during sensitive pheno-stage of maize growing. Aflatoxins are rarely isolated in Republic of Serbia, but there are conditions for their increased presence in imported feed components. Natural occurrence of ochratoxin A is more frequent than incidence of aflatoxins in climatic conditions of Republic of Serbia. Presence of mycotoxins produced by species of genera Fusarium, Aspergillus and Penicillium indicates potential risk of incidence of mycotoxicosis, especially in younger animal categories. For the purpose of protection of health of animals, realization of profit and high productivity in livestock production, it is necessary to explain factors which can cause animal intoxication, and to identify toxins and develop methodology for assessment of the potential toxicity of animal feed.
\end{abstract}

Key words: animal feed, toxigenic fungi, mycotoxins

\section{Introduction}

The significant advance in intensive animal production systems is at once the cause and the consequence of the increase in grain production. Production of poultry and swine, in particular, requires a large amount of grain to fulfil their dietary needs. For this reason grain production increases every year; and following 
harvest, most of the grain is stored until utilized. Fungi (mold) growth in grain is a normal occurrence in both the field and in storage. Fungi growth can spoil the nutritional aspects of the grain and also result in secondary metabolites that are highly toxic to animals, humans, and plants (Santin, 2005).

Mycopopulations which develop in the field contaminate plants and produce mycotoxins before harvesting (field fungi), whereas mycopopulations in storages contaminate plant products after harvesting (storage fungi), although in majority of cases they are same fungi species in both groups. Fungi from genera Fusarium, Alternaria and Cladosporium are mainly active in the field, whereas Penicillium and Aspergillus spp. are more active in conditions of storage spaces (Scudamore, 1993). At the same time, species which belong to genera Fusarium, Aspergillus and Penicillium are the most significant and most frequent toxin producers (Škrinjar et al., 2008). Although, in Republic of Serbia, species of Alternaria genus develop mostly on wheat grain (Lević et al., 2004), from the toxicological aspect the most important are species of Fusarium genus (Bočarov-Stančić, 1996). The contamination of crops in the field by mycotoxins is a combination of many factors, such as: the virulence of the infecting pathogens; the time of harvest, related to the mycotoxins concentration cycle; innate resistance of the crop to fungal infection; stresses: eg. soil salinity, water, insect attack, mineral deficiency, pollution; plants inherent ability to degrade mycotoxins enzymatically; types of mycotoxin produced (Harley, 1997).

Spores from moldy hay, silage, brewer's grain and suger-beat pulp may be inhaled or consumed by animals with deleterious effects termined „mycosis" (D'Mello, 2004). The latter may occur in cattle as a result of systemic transmission and subsequent proliferation in placental and foetal tissue.

Mycotoxins represent group of structurally different secondary fungi metabolites which are most frequent contaminants of different grains and other feed components, such as alfalfa hay, sunflower and soy bean meal, etc. (Harley, 1997). Maize and cereal crops with relatively high share in livestock feeds represent potentially high risk for health and production of livestock (pigs, poultry and cattle, since these plant species are very sensitive/susceptible to toxigenic Fusarium species and are often contaminated with fusariotoxins. For humans, food based on contaminated plants and products of animal origin, such as milk, cheese and meat products, represent the greatest risk of presence of mycotoxins (Lević, 2008). On livestock farms in Vojvodina, incidence of high level of fusariotoxin zearalenon (ZEA) was determined in samples of maize, soy bean and sunflower flour, imported to Republic of Serbia in period from 1996 to 2001 (Jajić et al., 2001).

Mycotoxins can cause health disorders in all animal species, and effects are mainly noticeable in high yielding animals in farm housing system since the consumption of concentrated feeds and/or food is significantly higher. Changes 
caused by mycotoxins depend on species and amount of mycotoxins in food, duration of their intake into organism, as well as on genetic (specie, breed, strain of animal), physiological (category, age, nutrition, disease) and exterior (climatic conditions, housing) factors (Sinovec et al., 2000).

Studies of the micro-biological quality of samples of feed for different species and categories of animals, collected on the territory of Republic of Serbia, indicate that livestock feed is most often contaminated with fungi of following genera: Fusarium (51.4-84.3\%), Aspergillus (54.4-79.2\%), Penicillium (30.968.1\%), as well as Mucor spp. and Rhizopus spp. (Krnjaja et al., 2007b, 2008bcd). According to Serbian legislation (Official journal of SFRY, 1990), investigated livestock feed was not compliant in 6.9-14.8\% of samples for young categories of animals, and $1.9-15.3 \%$ of samples for older animal categories (Krnjaja et al., $2007 b, 2008 b c d)$.

In Republic of Serbia, based on study of incidence of fungi on stored maize, intended for nutrition of animals, the period from June to October is the most critical for preservation of the quality of stored maize (Krnjaja et al., 2007a). In that period, number of present species ( 8 to 14 present of total 17 identified fungi genera) and frequency of fungi were the highest, especially of toxigenic species of the Fusarium (43.5-62.5\%) and Penicillium (10.0-33.5\%) genera. During autumn, from samples of feed for dairy cows, the widest spectrum of fungi species was isolated and the most present were species of Aspergillus genus (68.0\%), whereas Penicillium species were mostly present in summer (94.0\%) and winter period (68.0\%) (Škrinjar et al., 2008). According to these authors, during spring period the presence (56.0\%) of species from genera Fusarium, Mucor and Penicillium was equal.

For the purpose of achievement of conditions for high quality and high productive livestock production in Republic of Serbia, in this paper a review of factors is given which influence the presence of toxigenic fungi and their mycotoxins in animal feed, as well as review of control measures for reduction of mycotoxin production.

\section{Species of Fusarium genus and their mycotoxins}

In Republic of Serbia, species of Fusarium genus are the main causers of maize and cereal grain disease, which often results in decrease of yield, diminishing of technological qualities and contamination of plant and animal products with mycotoxins (Balaž et al., 1997; Lević et al., 2004; Stanković et al., 2008a). From maize grain approx. 30 different species of genus Fusarium were isolated. Species $F$. graminearum Schwabe is the most significant pathogen in wheat as well as maize (Bagi et al., 2000; Lević et al., 2001). Except F. graminearum, from maize grain often the following were isolated: $F$. 
verticillioides (Sacc.) Nirenberg, F. subglutinans (Wollenw. \& Reinking) Nelson, Toussoun \& Marasas $(=F$. moniliforme Sheldon) and $F$. proliferatum (Matsushima) Nirenberg, and in lower percentage $F$. oxysporum Schlecht., $F$. sambucinum Fuckel and F. poae (Peck) Wollenweber (Lević et al., 2001; Krnjaja et al., 2007a). European corn borer is the pest most present in Republic of Serbia, which can increase the contamination of the maize ear with species $F$. verticillioides up to $63.1 \%$ (Lević et al., 2004).

In previous years, in wheat grain species $F$. graminearum or $F$. culmorum (W.G. Smith) Saccardo were mainly isolated, but in recent years, beside $F$. graminearum, more often $F$. poae and $F$. verticillioides are isolated, and slightly less F. proliferatum, F. subglutinans and F. sporotrichioides Schrb. (Lević et al., 2004, 2009; Krnjaja et al., 2006; Stanković et al., 2007b; Krnjaja et al., 2008a). In 2005 , in wheat grain, for the first time $F$. langsethiae Torp \& Nirenberg was isolated (Lević et al., 2008b), which is also very toxigenic species (BočarovStančić et al., 2008).

In analysis of food samples for different animal species and categories the presence of $F$. verticillioides, $F$. subglutinans and $F$. proliferatum (Krnjaja et al., 2007b; Krnjaja et al., 2008b; Škrinjar et al., 2008; Lević et al., 2009) was most often established, especially of $F$. verticillioides (to 46,3\%) (Krnjaja et al., 2008b). In sunflower meal, of Fusarium species the following were most frequent: $F$. sporotrichioides, F. subglutinans and F. verticillioides (Bočarov-Stančić, 2006).

Toxigenic species $F$. oxysporum, $F$. solani, $F$. equiseti, $F$. proliferatum, $F$. avenaceum, $F$. tricinctum, $F$. sporotrichioides and $F$. graminearum were determined by Krnjaja et al. (2002) subsequent to isolation of pathogens from diseased alfalfa plants from four locations in Republic of Serbia. In seed of six alfalfa cultivars and three red clover cultivars, also in high and relative high percentage, following toxigenic species of Fusarium genus were isolated: $F$. verticillioides, $F$. proliferatum, F. oxysporum, F. solani (Mart.) Appel \& Wollenw. and F. subglutinans (Krnjaja et al., 2003, 2004).

Zearalenon (ZEA). So far over 300 different mycotoxins have been identified, of which especially important are fusariotoxins, zearalenon, T-2 toxin, deoxynivalenol and fumonisins (Marasas, 2000). Zearalenon (ZEA) or F-2 toxin is known world wide as mycotoxin causing estrogen syndrome (estrogenism) in pigs. Incidence of zearalenon in nature is caused by high air humidity and low temperatures. Of zearalenon derivatives the most important are alfa- and betazearalenol. Zearalenon is primarily produced by species $F$. graminearum, which causes rotting of maize root, stem and ear/grain. In significantly smaller quantities, zearalenon can also be produced by $F$. semitectum Berk \& Rav., $F$. oxysporum, $F$. verticillioides, $F$. subglutinans, F. solani, etc. (Meronuck and Concibido, 1996).

Lević et al. (2004) stated that in research carried out in eighties in Republic of Serbia, level of ZEA in maize varied from 200 to $7000 \mu \mathrm{g} \mathrm{kg}^{-1}$ in numerous 
samples with level of mycotoxins above the allowed limit. Bio-synthesis of ZEA in Republic of Serbia was most often established in species F. graminearum, in years with ample precipitation and low temperatures at the end of summer and beginning of autumn (Lević et al., 2004). Kordić et al. (1990) established in forage mixtures for gilts, pregnant sows and sows in lactation from two pig farms $35.0 \%$ of samples with ZEA whose amount varied from 200 to $1100 \mu \mathrm{g} \mathrm{kg}{ }^{-1}$. In year 1991, 50-70 $\mu \mathrm{g}$ $\mathrm{kg}^{-1}$ ZEA in samples of maize grain was established, collected from different locations in Republic of Serbia and which displayed symptoms of late contamination (Lević et al., 1993). In wheat samples collected in period 20052006, natural incidence of ZEA was established in 62.5\% of samples (Stanković et al., 2008a). According to EU regulations relating to maximum allowed amount of mycotoxins in human nutrition, $41.2 \%$ of studied samples had higher concentration of ZEA than allowed for consumption in non-processed form, and in $11.9 \%$ for production of bread flour and baby food.

Trichothecenes. Trichothecenes are group of mycotoxins with over 150 different but structurally similar compounds which inhibit synthesis of proteins in eukaryotes causing diseases in humans and animals. They are divided into four groups: A, B, C and D (Ueno, 1983), of which the most frequent and most significant in agriculture are those from groups A and B. Trichothecenes are produced by various fungi species which belong to different genera, such as: Trichothecium, Stachybotrys, Myrothecium, Cephalosporium, Trichoderma, Penicillium, Fusarium and other. However, the most trichothecenes have been isolated from cultures of fungi species of Fusarium genus. First trichothecene was isolated in 1848 from culture of fungi Trichothecium roseum (Persoon) Link ex S.F. Gray, from which the term/name of this group of mycotoxins derives. T-2 toxin and diacetoxyscirpenol (DAS) from group A and deoxynivalenol (vomitoxin, DON) from group B are most isolated and identified trichothecenes in agricultural products contaminated with Fusarium species. Low temperatures, high air humidity influence increased production of these mycotoxins.

Trichothecenes weaken the immune system of mammals in a way that they modify through immune cells immune responses and cause damage of other tissues (Meronuck and Concibido, 1996). Individually or in combination, trichothecenes can cause mycotoxicosis in animals, septic angina (ATA) in humans and other disorders. As main causes of these occurrences mainly DAS and T-2 toxin are stated (Joffe, 1974). Over 20 species of Fusarium genus, which are aggressive pathogens and have wide spectrum of hosts, were described as producers of trichothecenes. Among them F. sporotrichioides and F. poae are the most often producers of T-2 toxin and DAS, whereas $F$. crookwellense Burgess, Nelson \& Toussoun, $F$. culmorum, $F$. graminearum and $F$. sambucinum most often produce DAS and DON (Meronuck and Concibido, 1996). 
Natural incidence of trichothecenes of type A, such as T-2 and DAS toxin, are very important for Republic of Serbia. So, for instance, it was established that naturally dried maize, which is the most present method of drying in Republic of Serbia, contained $250-1750 \mu \mathrm{g} \mathrm{kg}^{-1}$ of T-2 toxin and $500-2000 \mu \mathrm{g} \mathrm{kg}^{-1}$ of DAS toxin, and artificially dried maize contained significantly lower level of these mycotoxins, 250-750 $\mathrm{g} \mathrm{kg}^{-1}$ (T-2) and $250 \mu \mathrm{g} \mathrm{kg}^{-1}$ (DAS) (Lević et al., 2004). Investigation by Stankovic et al. (2008b) show that in $14.8 \%$ of samples of wheat grain, 2005-2006 crop, were naturally contaminated with higher level of DON compared to allowed limit for utilization in non-processed form, in 3.7\% for production of paste and in $37.0 \%$ for production of baby food.

Fumonisins. Fumonisins are group of structurally similar mycotoxins which were isolated for the first time from cultures $F$. verticillioides, one of the most frequent maize contaminating species. Other species of genus Fusarium which produce these mycotoxins are $F$. proliferatum, $F$. anthophilum (A. Braun) Wollenw., F. dlamini Marasas, Nelson \& Toussoun, F. napiforme Marasas et al. and F. nygamai Burgess \& Trimboli (Thiel et al., 1991, Nelson et al., 1993). Fumonisins are grouped in four series: A, B, C and P. The most present fumonisins and directly connected to pathogenic effects are fumonisins of $\mathrm{B}\left(\mathrm{FB}_{1}, \mathrm{FB}_{2}, \mathrm{FB}_{3}\right.$, $\mathrm{FB}_{4}$ ) and $\mathrm{A}$ series (FA, $\mathrm{FA}_{1}$ and $\mathrm{FA}_{2}$ ) (Meronuck and Concibido, 1996). Studies have shown that less than $100 \mu \mathrm{g} \mathrm{kg}^{-1}$ of body mass daily is sufficient to cause toxic effect in different animal species, and less than $1 \mu \mathrm{g} \mathrm{kg}^{-1}$ of body mass of daily intake of $\mathrm{FB}_{1}$ for humans (Petersen and Thorup, 2001, loc. cit. Đilas et al., 2003).

There are only few data on incidence of fumonisins in Republic of Serbia in relation to frequency of isolation of fungi species which produce them. In wheat samples, presence of fumonisins (FB1 and FB2) was determined in concentration of 250-640 $\mathrm{g} \mathrm{kg}^{-1}$ (Protić, 2000). Presence of FB1 in concentration of 45-70 $\mu \mathrm{g}$ $\mathrm{kg}^{-1}$, was determined in two of 15 samples of maize harvested in 2002 and $450 \mu \mathrm{g}$ $\mathrm{kg}^{-1}$ in one of 5 samples of soy bean flour from import (Đilas et al. 2003). Considering high concentration of $\mathrm{FB}_{1}\left(>5.000 \mu \mathrm{g} \mathrm{kg}{ }^{-1}\right)$, wheat of the 2005-2006 crop only in $25.9 \%$ cases could have been used in human nutrition (Stanković et al., 2008a,c).

\section{Species of genera Aspergillus and Penicillium and their mycotoxins}

In Republic of Serbia, fungi of genera Aspergillus and Penicillium are often isolated in food samples for different species and categories of animals, as well as from maize grain after harvest or during storage (Krnjaja et al., 2007a,b, $2008 b, c, d)$. According to data presented by Krnjaja et al. (2007b, 2008d) A. flavus Linkis the most often isolated species in different livestock foods, whereas in lower 
percentage A. fumigatus Fresenius, A. ohraceus Wilh and A. niger van Tiegh were also isolated.

Moldness of the maize ear is caused by several species of the genus Penicillium. These species adapt very well to different conditions of the environment, and symptoms can be different - from internal discolouration ("blue eye") of the germ to full covering of the maize ear with blue-green mycelia.

Moldness of maize ear of type aspergillosis is most often caused by three species of genus Aspergillus: A. flavus, A. paraisiticus Spear and A. glaucus Link ex Grey. Similar to Penicillium species, also Aspergillus spp. are very good adapted to different conditions of storage, especially in regard to lower air humidity. Disease starts at the top of maize ear, or it follows the tracks left by insects, and symptoms are noticeable in the form of grey-green powdery mycelia. Hot and dry summers favour the development of disease (Stanković et al., 2007a).

Aflatoxins. The aflatoxins are a group of closely related, highly toxic, mutagenic and carcinogenic compounds produced primarily by $A$. flavus and $A$. parasiticus. Almost all strains of $A$. parasiticus are toxigenic, and aflatoxin synthesis in A. flavus varied considerably depending on the strain. Contrary to the opinion that aflatoxins are secondary metabolites exclusively of the stated molds, there are opinions that there are also other species (A. niger, A. ruber Thom and Church, Penicillium citrinum Thom, P. digitatum Sacc., Rhizopus spp., Mucor mucedo Fresenius) with ability of aflatoxin synthesis, although only in traces (Resanović, 2000). There are 4 naturally occurring aflatoxins $\mathrm{B}_{1}, \mathrm{~B}_{2}, \mathrm{G}_{1}, \mathrm{G}_{2}$ (thus designated because of the colour the emit, blue and green under UV light). Aflatoxins have a high potential to contaminate animal feeds that were grown or stored in an environment favourable for the growth of the fungi. Aflatoxin contamination of maize and other commodities has been and continues to be a major problem in many parts of the world (Meronuck and Concibido, 1996). The highest levels of aflatoxin are formed in plant products which are visibly damaged and infected, and poorly stored, badly harvested crops are still the most likely to be contaminated with dangerously high levels of aflatoxin. However, it is most often the relatively low water content present in stored products that creates an environment uniquely suited to the growth of the partially xerophilic species of both Aspergillus and Penicillium to the extent that both genera almost totally dominate the fungal flora of such environments (Harley, 1997). Aflatoxin $\mathrm{B}_{1}$ was the first mycotoxin isolated from the food which caused death of 100.000 turkeys in 1960 in England. Aflatoxins have been determined world wide in different types of animal foods, and their quantity varies depending on numerous factors. There is great difference in frequency of contamination of livestock food in particular years. In favourable, suitable years, fungi synthesize aflatoxins in 2 days at the temperature between 20 and $40^{\circ} \mathrm{C}$ and humidity of over $13 \% . \mathrm{AB}_{1}$ is carcinogenic and hepatotoxic. All species and categories of domestic animals are susceptible and 
sensitive to aflatoxins, also poultry, laboratory animals and fish. The most resistant are sheep and rabbits. Younger animals are more sensitive than older ones, gravid than non-gravid animals, and males than females (Rajić, 2000). Škrinjar et al. (1992) published that some samples of food for dairy cows were contaminated with $\mathrm{AB}_{1}$ and $\mathrm{AM}_{1}\left(5-16 \mu \mathrm{g} \mathrm{kg}^{-1}\right)$, but that none of the analyzed milk samples was contaminated with these aflatoxins. Acute signs, when observed, might include anorexia, depression, ataxia and epistases. Chronic primary mycotoxicosis resulting from low level dietary intake of aflatoxin have been well documented; reduced weight gain, reduced milk yield, reduced feed intake and feed conversion, icterus and decreased appetite (Meronuck and Concibido, 1996; Harley, 1997).

Ochratoxins. These mycotoxins are bio-synthesized by fungi of genera Aspergillus and Penicillium. There are several groups of ochratoxins: A, B, C, alfa, beta. In Republic of Serbia, of special importance are ochratoxin A (OA) and ochratoxin B (OB) (Rajić, 2000). Ochratoxin A is produced primarily by $A$. ochraceus and $P$. verrucosum Dierckx on a variety of substrates, including cereal grains and oil seeds. Mycotoxin production is optimised at higher temperatures $\left(12-37{ }^{\circ} \mathrm{C}\right)$ for A. ochraceus. P. verrucosum, on the other hand, has better mycotoxin production at the cooler temperatures $\left(4-31^{\circ} \mathrm{C}\right)$. Both organisms are classified as storage of OA under poor storage conditions for commodities that provide optimum conditions, e.g. increased moisture for enhanced fungal development and mycotoxin production. Animal studies have shown OA to be a potent nephrotoxin, immune suppressant, teratogen, carcinogen as well as a potent foetoxic agent. In most animals studied, the target organ of OA is the kidney. It causes necrosis of the proximal tubules. Consumption of feeds contaminated with OA results in nephropathy in animals, especially in swine and poultry (Harley, 1997; Manning, 2005).

In maize and sunflower flour samples, Mašić et al. (2003) established presence of $\mathrm{OA}$ and $\mathrm{AFB}_{1}$ in average concentrations of $36-37$ to $69-78 \mu \mathrm{g} \mathrm{kg}^{-1}$. In samples of food for poultry presence of OA in concentration of 140 to $165 \mu \mathrm{g} \mathrm{kg}^{-1}$ was established (Mašić et al., 2003).

\section{Measures for safe storing of animal food}

Control of mycotoxin bio-synthesis in practice can be divided into two phases: prevention of fungi development and of production of mycotoxins and detoxication of existing mycotoxins in animal food. Prevention of food contamination by toxicogenic molds is the most rational and economically justified method for prevention of potential consequences of the action of their metabolites on animal and human health.

For the purpose of prevention of mycotoxin bio-synthesis, it is primarily necessary to take measures which prevent development of fungi in the field and 
storage spaces. These measures include: growing of genotypes resistant to toxigenic fungi species and insects, optimal agro-technical measures, health control of the seed, harvest in full maturity, separation of seed with pathological changes and maintenance of optimal conditions for storage of harvest products. General principle is to store only dry grain which is cooled, dried to approx. $13 \%$ of moisture, intact, healthy and purified of foreign ingredients or substances, in storage room whose structure and organization provide preservation of the quality before consumption (Stanković et al., 2007a; Lević et al., 2008a).

When foods and/or feeds have been contaminated with mycotoxins, measures are implemented which enable elimination of mycotoxins by detoxication or degradation into less toxic or completely non-toxic compounds by process of detoxification. Detoxication represents procedure by which toxic substances are removed from food by selective solvents or procedures, whereas detoxification is defined as conversion of toxic substances into non-toxic derivatives (Sinovec et al., 2000).

There are numerous methods which can be used to carry out decontamination of livestock food contaminated with mycotoxins. Different physical and chemical methods are recommended for detoxification of livestock food contaminated with mycotoxins. However, only few o them (for instance destruction by ammonia treatment, ammonization) are accepted for implementation in practice. By degradation of mycotoxins using selective micro-organisms, mycotoxins are removed without significant losses of the nutritive value of animal food. Fermentation is one of the oldest, easiest and cheapest ways of food preservation. For this purpose lactic acid bacteria and yeasts are used (Biernasiak, 2006).

In practice, often in animal food different materials are used which adsorb mycotoxins from food in digestive tract of the animal. Zeolite and clay minerals adsorb at their surface with more or less efficiency different mycotoxins. These minerals belong to group of alumosilicate minerals. Their efficiency for mycotoxin adsorption depends on the capacity of adsorption, crystal structure and superficial electricity on one side, as well as on traits present in mycotoxins on the other (Sinovec et al., 2006). The best known and most efficient preparations of mineral zeolite are Min-a-Zel and Min-a-Zel Plus. These products gave the best results, from the aspect of number and species of mycotoxins being adsorbed by these preparations, as well as from the aspect of critical mass of the organic phase which allows uninterrupted application in food for animals (Tomašević- Čanović et al., 2001).

Recently, different biological adsorbance are applied which competitively bind mycotoxins and in this way prevent their harmful effect. Modified glucoman obtained from cell walls of Saccharomyces cerevisiae yeast (preparation Mycosorb) successfully reduces certain individual as well as combined harmful effects of aflatoxins, ochratoxins and T-2 toxins (Devegowda and Murthy, 2005). 


\title{
Conclusion
}

Fungi and their mycotoxins have significant economic and commercial impact, in that both the productivity and nutritive value of the infected cereal and forage is affected. Contamination by molds affects both the alimentary value and organoleptic characteristic of feed and entails a risk of toxicosis.

Undoubtedly, mycotoxicoses of animals occur, affecting livestock, health and production efficiency, however the stuble effects which occur are difficult to assess regarding economic losses. Efforts continue in determining the occurrence of mycotoxins in foods and feed through diagnostic procedures, surveys and epidemiological studies.

Imperative to the task of minimising mycotoxin production and contamination of the food supply is the development of methods to control their formation, or the development of newer methods to detoxify or decontaminate the affected commodities safely.

\section{Acknowledgment}

Research was financed by the Ministry of Science and Technological Development of Republic of Serbia within project TR-20046.

\section{Prisustvo toksigenih vrsta gljiva i mikotoksina u stočnoj hrani u Republici Srbiji}

\author{
V. Krnjaja, J. Lević, S. Stanković
}

\section{Rezime}

Klimatski uslovi i gajenje žita na velikim površinama u Republici Srbiji pogoduju razvoju brojnih toksigenih vrsta, kao što su Fusarium spp., Aspergillus spp. i Penicillium spp., i kao rezultat toga je i česta kontaminacija hrane za životinje njihovim toksičnim produktima. U Republici Srbiji su u hrani za životinje najčešće utvrđene gljive iz roda Fusarium, kao i njihovi mikotoksini. Od Fusarium vrsta najčešća je $F$. graminearum, a od toksina zearalenon, bilo u zrnu kukuruza ili pšenice koje su najčešće sirovine za stočnu hranu. Razvoj ove gljive i biosinteza zearalenona najčešće zavise od kišnog perioda u trećoj dekadi maja kada je pšenica u fenofazi cvetanja ili od obilnih padavina i niskih temperatura pri kraju leta $i$ početkom jeseni kada je osetljiva fenofaza kukuruza. Aflatoksini su retko izolovani 
u Republici Srbiji, ali postoje uslovi za veće prisustvo prilikom uvoza komponenti hrane za životinje. Prirodna pojava ohratoksina A je češća od pojave aflatoksina u klimatskim uslovima Srbije. Prisustvo mikotoksina koje produkuju vrste roda Fusarium, Aspergillus i Penicillium ukazuje na potencijalni rizik od pojave mikotoksikoza, posebno za mlađe kategorije životinja. U cilju zaštite zdravlja životinja, ostvarivanja dobiti i visoke produktivnosti u stočarskoj proizvodnji, postoji potreba da se objasne faktori koji mogu prouzrokovati intoksikaciju životinja, kao i da se toksini identifikuji i razvije metodologija za ocenu potencijalne toksičnosti hrane za životinje.

\section{References}

BAGI F., BALAŽ F., ŠKRINJAR M. (2000): Količina mikotoksina zearalenona u zrnima pšenice od izolata Fusarium graminearum različite patogenosti. XI jugoslovenski simpozijum o zaštiti bilja, Zlatibor, 4-9. decembar 2000. godine. Zbornik rezimea, 31 .

BALAŽ F., ŠKRINJAR M., DOPUĐA M. (1997): Fuzariozna oboljenja žita (rasprostranjenost, štetnost i mere zaštite). III jugoslovensko savetovanje o zaštiti bilja. Zlatibor, 1-6. decembar 1997. godine. Zbornik rezimea, 15.

BIERNASIAK J., PIOTROWSKA M., LIBUDZISZ Z. (2006): Detoxification of mycotoxins by probiotic preparation for broiler chickens. Mycotoxin Research, 22, 4, 230-235.

BOČAROV-STANČIĆ A. (1996): Učestalost Fusarium spp. i njihovih mikotoksina u pšeničnom zrnu. U monografiji "Proizvodnja i prerada žita i brašna". Tehnološki fakultet, Zavod za tehnologiju žita i brašna, Novi Sad, 131-142.

BOČAROV-STANČIĆ A., ADAMOVIĆ M., KOMATINA R., BIJELIĆ M., RUŽIN S. (2006): Prisustvo potencijalno toksigenih Fusarium vrsta u suncokretovoj sačmi. Biotechnology in Animal Husbandry, 22, 717-726.

BOČAROV-STANČIĆ A., LEVIĆ J., STANKOVIĆ S., TANČIĆ S., KRNJAJA V., SALMA N. (2008) Toxigenic potential Fusarium langsethiae isolates from Serbian wheat kernels. Cereal Res. Commun., 26, Supplementum B, 345-346.

DEVEGOWDA G., MURTHY T.N.K. (2005): Mycotoxins: effects on poultry performance and health. Pp. 25-56. In: Diaz D.E. (eds), The mycotoxin blue book. Nottingham University Press, Nottingham, United Kingdom.

ĐILAS S., ABRAMOVIĆ B., MAS̆IĆ Z. (2003): Rasprostranjenost fumonizina i metode njihovog određivanja. 15. Savetovanje veterinara Srbije, Zlatibor, 9-13. septembar, 2003. godine. Zbornik radova i kratkih sadržaja, 110-118.

D'MELLO J.P.F (2004): Contaminants and toxins in animal feeds. Pp. 107-128. In: FAO (ed.), Assessing Quantity and Safety of Animal Feeds. 
HARLEY R.M. (1997): Mycotoxins in cereals. In: D'Mello J.P.F. (ed.), Mycotoxins and environmental health. Handbook for SAC Mycotoxin Workshop, Edinburgh.

JAJIĆ I., TERZIĆ V., JURIĆ V., RADANOV-PELAGIĆ V. (2001): Mycotoxins of maize, soya bean and sunflower meal 1996-2001. A periodical of Scientific Research on Field and Vegetables Crops. Institute of Field and Vegetable Crops, Novi Sad, 194-200.

JOFFE A.Z. (1974): Toxicity of Fusarium poae and F. sporotrichioides and its relation to Alimentary Toxic Aleukia. Pp. 229-261. In: Purchase I.F.H. (ed.), Mycotoxins. Elsevier, Amsterdam-Oxford-New York.

KORDIĆ B., SIMIĆ M., LAZAREVIĆ D. (1990): Uticaj niskih doza mikotoksina zearalenona na reproduktivna svojstva svinja. Veterinarski glasnik, 44, 2, 151-155.

KRNJAJA V., LEVIĆ J., IVANOVIĆ M., TOMIĆ Z. (2002): Fusarium species causing alfalfa crown and root rot in Serbia. $7^{\text {th }}$ European Seminar on FusaiumMycotoxins, Taxonomy and Pathogenicity and WG-4 Cost 835 Action Workshop (Mycotoxins in cereals). Poznan, Poland, 4-7 September 2002. Book of Abstracts, 99. KRNJAJA V., LEVIĆ J., IVANOVIĆ M., TOMIĆ Z. (2003): Fusarium species associated with seeds of alfalfa cultivars. Czech Journal of Genetics and Plant Breeding, 39, Special Issue, 275-278.

KRNJAJA V., LEVIĆ J., IVANOVIĆ M., TOMIĆ Z. (2004): Incidence of Fusarium species on red clover seed. Biotechnology in Animal Husbandry, 20, 1-2, 101-107.

KRNJAJA V., LEVIĆ J., TOMIĆ Z., STANKOVIĆ S. (2006): The participation of potentially toxigenic Fusarium species in mycopopulations isolated from maize grain. Journal of Mountain Agriculture on the Balkans, 9, 4, 532-541.

KRNJAJA V., LEVIĆ J., TOMIĆ Z., NEŠIĆ Z., STOJANOVIĆ LJ., TRENKOVSKI S. (2007a): Dynamics of incidence and frequency of populations of Fusarium species on stored maize grain. Biotehnology in Animal Husbandry, Book 1, 23, 5-6, 589-600.

KRNJAJA V., LEVIĆ J., TOMIĆ Z., STOJANOVIĆ LJ., TRENKOVSKI S., NEŠIĆ Z., MARINKOV G. (2007b): Prisustvo potencijalno toksigenih gljiva u hrani za životinje sa posebnim osvrtom na vrste rodova Aspergillus i Fusarium. Biotehnology in Animal Husbandry, 23, 102, 95-103.

KRNJAJA V., LEVIĆ J., STANKOVIĆ S. (2008a): Pathogenic fungi on wheat grain in Serbia. Journal of Plant Pathology, 90, 3, Supplement, 84.

KRNJAJA V., STOJANOVIĆ LJ., LEVIĆ J., TOMIĆ Z., NEŠIĆ Z. (2008b): Contamination of animal feed with potentially toxigenic fungi with special focus on species of genus Fusarium. $43^{\text {rd }}$ Croatian and $3^{\text {rd }}$ International Symposium on Agriculture, 18-21 February 2008, Opatija, Croatia. Proceedings, 2, 823-826. 
KRNJAJA V, STOJANOVIĆ LJ., CMILJANIĆ R., TRENKOVSKI S., TOMAŠEVIĆ D. (2008c): The presence of potentially toxigenic fungi in poultry feed. Biotechnology in Animal Husbandry, 24, 5-6, 87-93.

KRNJAJA V., STOJANOVIĆ LJ., TOMIĆ Z., NEŠIĆ Z. (2008d): The presence of potentially toxigenic fungi in dairy cattle feed with focus on species of genus Aspergillus. Journal of Mountain Agriculture on the Balkans, 11, 4, 621- 630.

LEVIĆ J. (2008): Vrste roda Fusarium. Cicero, Beograd, 1226.

LEVIĆ J., IVANOVIĆ D., PETROVIĆ T., STOJKOV S. (2001): Ambijentalni uslovi za pojavu fuzarioza kukuruza i biosintezu mikotoksina. V jugoslovensko savetovanje o zaštiti bilja. Zlatibor 3-8. decembar, 2001. godine. Zbornik rezimea, 46. LEVIĆ J., PENČIĆ V., IVANOVIĆ D., BOČAROV-STANČIĆ, A. (1993): Maize ear and associated fungi in field and crib environment. Archives for Biology Sciences, 45, 37-44.

LEVIĆ J., STANKOVIĆ S., BOČAROV-STANČIĆ A., ŠKRINJAR M., MAŠIĆ Z. (2004): The overview of toxigenic fungi and mycotoxins in Serbia and Montenegro. Pp. 201-218. In: Logrieco A., Visconti A. (eds), An overview of toxigenic fungi and mycotoxins in Europe, Kluwer Academic Publishers, Dordrecht, Boston, London.

LEVIĆ J., STANKOVIĆ S., KRNJAJA V. (2008a): Štetni mikroorganizmi u uskladištetnom žitu. Kljajić P. (ed.), Zaštita uskladištenih biljnih proizvoda od štetnih organizama, Vizartis, Beograd, 39-66.

LEVIĆ T.J., STANKOVIĆ Ž.S., KRNJAJA S.V., BOČAROV-STANČIĆ S.A. (2009): Fusarium species: The occurrence and the importance in agriculture of Serbia. Zbornik Matice Srpske/ Proceedings for Nature Sciences, 116, 33-48.

LEVIĆ J., STANKOVIĆ S., KRNJAJA V., KOVAČEVIĆ T., TANČIĆ S., BOČAROV-STANČIĆ S. (2008b): Fusarium head blight and grain yield losses of Serbian wheat . Cereal Res. Commun., 26, Supplementum B, 513-514.

MANNING B. (2005): Mycotoxins in aquaculture. Pp. 139-156. In: Diaz, D.E. (eds), The mycotoxin blue book. Nottingham University Press, Nottingham, United Kingdom.

MARASAS W.F.O. (2000): Fusarium mycotoxins in the third millennium. The $6^{\text {th }}$ European Fusarium Seminar and Third COST 835 Workshop of Agriculturally Important Toxigenic Fungi, 42. Berlin, Germany, 11-16 September 2000.

MAŠIĆ Z., BOČAROV STANČIĆ A., SINOVEC Z., ĐILAS S., ADAMOVIĆ M. (2003): Mycotoxin in feed for animals in the Republic of Serbia. 10th Symposium Food Technology for Animal Safety and Quality. Vrnjačka Banja, Serbia and Montenegro. Book of Prooceedings.

MERONUCK R., CONCIBIDO V. (1996): Mycotoxins in feed. Feedstuffs, 68, 30, 139-145.

MUNTAÑOLA-CVETKOVIĆ M., BORISAVLJEVIĆ J., KORDIĆ B. (1982): Vrste Fusarium kod kukuruza i njegovih prerađevina u Jugoslaviji. (Mikotoksini 
koje mogu proizvoditi). Simpozijum o mikotoksinima (Sarajevo, 14. decembar 1979. godine). Posebna izdanja knjiga LX. Odeljenje medicinskih nauka, Knjiga 10. Akademija nauka i umjetnosti Bosne i Hercegovine, pp. 149.

NELSON P.R., DESJARDINS A.E., PLATTNER R.D. (1993): Fumonisins, mycotoxins produced by Fusarium species: biology, chemistry, and significance. Ann. Rev. Phytopathol., 31, 233-252.

OFFICIAL JOURNAL OF SFRY 2/90/SLUŽBENI LIST SFRJ (1990): Pravilnik o maksimalnim količinama štetnih materija i sastojaka u stočnoj hrani, 2, 27.

PROTIĆ N. (2000): Mycotoxin in grain of and wheat products as a result of infection with Fusarium spp. fungi. Ph.D. Thesis. University of Belgrade, Faculty of Agriculture, Belgrade-Zemun, pp. 184.

RAJIĆ I. (2000): Plesni, mikotoksini i mikotoksikoze domaćih životinja. Savetovanje ITNMS, 3-15.

RESANOVIĆ R. (2000): Značaj aflatoksina u veterinarskoj medicini. II Sav., Budva, 12-16. jun 2000. godine. Clinica veterinaria, 178-182.

SANTIN E. (2005): Mold growth and mycotoxin production. Pp. 225-234. In: Diaz, D.E. (eds), The mycotoxin blue book. Nottingham University Press, Nottingham, United Kingdom.

SCUDAMORE K.A. (1993): Mycotoxins in stored products: myth or menace. International Biodeterioration \& Biodegradation, 32, 191-203.

SINOVEC Z., PALIĆ T., IVETIĆ V. (2000): Značaj mikotoksikoza u veterinarskoj medicini. II Sav., Budva, 12-16. jun 2000. godine. Clinica veterinaria, 167-177.

SINOVEC J.Z., RESANOVIĆ M.R., SINOVEC M.S. (2006): Mikotoksini: pojava, efekti i prevencija. Univerzitet u Beogradu, Fakultet veterinarske medicine, 236.

STANKOVIĆ S., KRNJAJA V., CVIJANOVIĆ G., STANKOVIĆ G. (2007a): Zaštita uskladištenog kukuruza od patogenih vrsta gljiva. Međunarodni naučni skup „Multifunkcionalna poljoprivreda i ruralni razvoj II“ - očuvanje ruralnih vrednosti, Beogad-Beočin, 6-7. decembar 2007. godine. Tematski zbornik, Druga knjiga, 1204-1212.

STANKOVIĆ S., LEVIĆ J., KRNJAJA V., BOČAROV-STANČIĆ A., TANČIĆ S., KOVAČEVIĆ T. (2007b): Frequency of toxigenic Fusarium species and fusariotoxins in wheat grain in Serbia. Zbornik Matice srpske/Proceedings for Nature Sciences, 113, 93-102.

STANKOVIĆ S., LEVIĆ J., PETROVIĆ T. (2008a): Toksikološki profil kompleksne vrste Gibberella fujikuroi poreklom sa kukuruza u Srbiji. Simpozijum o zaštiti bilja BiH, Sarajevo 16-18. decembar 2008. godine. Zbornik rezimea, 71-72.

STANKOVIĆ S., LEVIĆ J., TANČIĆ S., KRNJAJA V. (2008c): Kontaminacija semena zrna pšenice fumonizinom u Srbiji. IX Savetovanje o zaštiti bilja, Zlatibor, 24-28. novembar 2008. godine. Zbornik rezimea, 56-57. 
STANKOVIĆ S., TANČIĆ S., LEVIĆ J., KRNJAJA V. (2008b): Production of deoxinivalenol by Fusarium graminearum and Fusarium culmorum isolated from wheat kernels in Serbia. Cereal Res. Commun., 36, Supplementum B, 395-396. ŠKRINJAR M., AČ M., KRAJINOVIĆ M., POPOVIĆ-VRANJEŠ A. (2008): Zdravstveni i ekonomski značaj prisustva toksigenih plesni i mikotoksina u stočnoj hrani. Savremena poljoprivreda, 57, 3-4, 26-34.

ŠKRINJAR M., STUBLLEFIELD R.D., VUJIČIĆ I.F., STOJANOVIĆ E. (1992): Distribution of aflatoxin-producing molds and aflatoxins in dairy cattle feed and raw milk. Acta Microbiologica Hungarica, 39, 175-179.

THIEL P.G, SHEPHARD G.S, SYDENHAM E.W., MARASAS W.F.O., NELSON P.E., WILSON T.M. (1991): Levels of fumonisins $B_{1}$ and $B_{2}$ in feeds associated with confirmed cases of equine leukoencephalomalacia. J. Agric. Food Chem., 39, 109-111. TOMAS̆EVIĆ-ČANOVIĆ M.R., DAKOVIĆ A., DUMIĆ M., VUKIĆEVIĆ O. (2001): Mineralni adsorbenti mikotoksina Min-a-zel i Min-a-zel Plus. Institut za tehnologiju nuklearnih i drugih mineralnih sirovina, Beograd, 1-9.

UENO Y. (1983): Trichothecenes - chemical, biological and toxicological aspects. Kodansha LTD., Tokyo and Elsevier, Amsterdam-Oxford-New York, pp. 316. 